\title{
THE INFLUENCE OF ISO 9000 AND STRATEGIC ROLE OF MSDM TOWARDS PERFORMANCE OF AN ORGANIZATION: SURVEYS AT ISO 9000 STANDARDIZED PUBLIC HEALTH CENTERS IN CENTRAL SULAWESI, INDONESIA
}

\author{
Syamsuddin \\ Faculty of Economics, University of Tadulako, Indonesia \\ E-mail: syam singga@yahoo.co.id
}

\begin{abstract}
Despite of several advantages it has, implementation of ISO 9000 has several shortcomings, namely additional costs to get ISO certification, increasing workload, little or no attention towards personal development, lack of attention towards supporting functions within an organization, less room for employees to think creatively as employees are forced to work according to existing procedures and rules. The strategic role of MSDM can have positive effect towards performance of organization of an organization. In accordance to the research gap, analysis towards the variables or domains of the strategic role of MSDM that supports performance of organization of an organization is necessary.
\end{abstract}

\section{KEY WORDS}

ISO 9000, MSDM strategic role, performance, public health center.

Instead of seeking profit (profit-oriented), the main objective of public sector organizations, more particularly government organizations responsible for public health service is to meet the needs of the community. The Institute of Medicine (IOM) states that health care services today are too often harmful and fail to provide benefits to society (Institute of Medicine, 2001). Poor service quality is usually associated with complex production process design, instead of lack of willingness, skill, or intention of the employees (Berwick, 1989). Studies have discussed the benefit of ISO 9000 (Carson, 2004). It is reported that very few health care organizations use ISO 9000 as their standard (Sluijs and Wagner, 2000). Implementation of ISO 9000 in hospitals or at other health facilities is currently limited to the desire to obtain certification for its department alone (Van den Heuveletal., 1998).

Researchers have conducted many investigations about the main underlying reasons for companies to get ISO certification, difficulties they encountered to obtain ISO certification and the benefits they get having obtained the certification. Although ISO certification brings several benefits for the companies, , it also has also some disadvantages such as additional costs to get ISO certification, increasing workload, little or no attention towards personal development or attention towards supporting functions within an organization (Singels, et.al., 2001). Furthermore, ISO certification provides less room for employees to think creatively as employees are forced to work according to existing procedures and rules. Critics tend to say that ISO certification involves a lot of extra costs, and does not seem to benefit. Jones, et.al., (1997) stated that obtaining an ISO certificate was a "hollow achievement".

Various empirical studies conducted by the researchers disclosed that the strategic role of MSDM can positively affect the performance of the organization (Becker \& Huselid, 1998; Huselid, 1995; Terpstra \& Rozell, 1993). Nevertheless, in accordance to the research gap in this study, it is necessary to conduct analysis towards the variables or domains of the strategic role of MSDM that can support performance of organization of an organization. The relationship between the strategic role of MSDM towards performance of organization of organization will be tested in this study. Thus, the background and the research gap studyare one of the reasons why this research is important $t$.

The finding of (Maruf, Ali and Lam, 2007) study states that the implementation of ISO 9000 is a process shifting culture of organization of an organization in order to achieve desired performance. The findings of the (Katerina and Tsiotras, 2001) research mention ISO 
9000 can enhance quality culture and quality commitment as well as give significant operational benefits to ISO 9000 certified companies. However, the contribution of ISO 9000 is found to be higher for small and medium-sized companies which have lower performance of organization before ISO 9000 certification. The theory shows that certification using ISO 9000 as the standards can reduce information asymmetry in the supply chain and thus result in a competitive advantage for certified companies. The results showed that certified facilities or facilities grew faster after certification. (Ann and Andrew, 2006).

It is pivotal to identify the strategic role of MSDM that can be used as a standard measure to see how much contribution the role has to help companies achieving their business targets more quickly, and supporting long-term survival of the companies in a predictable environment (Cho, 2004). Furthermore, many academics and professionals disagree "what and how to measure the strategic role of MSDM" effectively (Cho \& Mayer, 2003). Ulrich (1997) proposes several domains of MSDM strategic role that can positively affect performance of organization. To address the domain gaps in measuring the strategic role of MSDM that contributes to performance of organization, this research will develop model and measurement of generic MSDM domains as best practices for academics. In addition, there has been no specific published research on the strategic role of MSDM that can support culture of organization and ultimately leads to performance of organization. In conclusion, this research addresses the problem.

Based on the research gap above, the statements of the problems are:

Does implementation of ISO 9000 affect performance of the ISO-standardized public health centers in Central Sulawesi?

Does MSDM strategic role affect performance of ISO-standardized public health centers in Central Sulawesi?

\section{LITERATURE REVIEW}

ISO 9000. Syamsuddin (2006) mentioned implementation of ISO 9000 (product, implementation, and role of management) had both simultaneous and partial influence towards performance of large scale wood industry in Palu. This meant that the performance of large-scale timber industry in Palu was determined based on several aspects, their product, implementation, and role of management.

Implementation of ISO 9000 into the product, implementation and management of the wood processing industry in Donggala, Central Sulawesi was able to explain partial influence of ISO 9000 towards the industry. ISO 9000 (product, implementation and management) had simultaneous effect towards the performance of the wood processing industry in Donggala, Central Sulawesi. (Ismail and Syamsuddin, 2007).

Dimensions of quality namely reliability, responsiveness, assurance, empathy and tangible had simultaneous influence towards the satisfaction the patients of the public health centers in Central Sulawesi. Seen from the variables of service quality ,reliability, responsiveness, assurance, empathy and tangible, there is difference between the public health center implementing TQM and those who did not (Mattulada A and Syamsuddin, 2008).

Implementation of ISO 9000 quality system from product aspect, implementation aspect and management role aspect partially able to explain its effect on public hospital performance in Palu city of Central Sulawesi. The impact of quality system implementation with ISO 9000 approach (product aspect, implementation aspect, and management role aspect) influence simultaneously to the performance of public hospital in Palu city of Central Sulawesi. (Sulaeman M and Syamsuddin, 2008).

Implementation of ISO 9000 on product, implementation and management was able to explain partial influence of ISO 9000 towards the performance of the TQM public health centers in Palu. The implementation of ISO 9000 on the product, implementation, and management had simultaneous influence towards the TQM performance of the public health centers in Palu (Sulaeman M and Mukhtar T, 2009). 
Human resource development system (career planning and education / training) had significant effect towards intellectual capital with probability lower than $\alpha=0.05$. This meant that career planning and education / training had positive effect towards intellectual capital of the employees of the public health centers in Palu. Human resource development system (career planning and education / training) affected the performance of the public health centers in Palu employees but the influence was not significant. (Syamsul Bahri DP and Syamsuddin, 2009).

The literature review showed that there were a lot of studies discussing ISO 9000 with a focus on describing motivation or obstacles in adopting ISO 9000, impact of quality management, internal benefitsand effects of ISO 9000 towards performance of organization (Lee and Palmer, 1999; Boiral, 2003). Three factors caused some obstacles towards the findings of the studies. First, most of the studies were conducted in manufacturing sector, with relatively few studies conducted in other sectors or across industries. Second, most researchers assumed that ISO 9000 was a "mechanistic, consensual and monolithic" system (Boiral, 2003: 720). Third, while differences between manufacturing and organizational services were recognized, contingent issues related to universal application of innovation management such as ISO 9000 were significantly researched and applicable across sectors.

A number of researchers investigated the experience of service organizations with ISO 9000. Dicketal. (2002) study involved large service organizations in the United Kingdom and showed that organizations registered in ISO 9000 were of a higher quality than unregistered companies. McAnn and Canning (2001) described professional services (quantity surveys) of companies from Northern Ireland that signed up for marketing and the purpose of internal process improvement. A number of studies in the computer software sector had shown that organizations had had difficulties with ISO 9000 (Stelzer et al, 1997; McArn and Fulton, 2002). While most of this research had acknowledged that the requirements of the service industry were different from those in the manufacturing sector, they provided little evidence that the issues identified above had been addressed.

Using a variety of approaches, studies were attempting to demonstrate the intrinsic value of ISO 9000 and implicitly suggested that unregistered organizations should imitate registered organizations. Benefits included improved routine efficiency, internal quality, total quality (Carlsson and Carlsson, 1996), employee skills, customer service, employee morale and processes (Beattie and Sohal, 1999). Registered organizations performed better than unregistered organizations on several dimensions of quality management (Terziovski et al., 2003), particularly in terms of process improvement and quality measurement (Carr et al., 1997). In short, this model assumed that organizations registered with ISO 9000 may act as role models for unregistered organizations.

Rayner and Porter (1991), Street and Fernie (1992), and Taylor (1995a, 1995b)) demonstrated that organizations were applying for various reasons, by being the most prominent external customer motivational pressure, internally oriented process and product enhancements, and using opportunistic as a marketing tool. Lee and Palmer (1999) and Hughes, et. al (2000) suggested that the main motivations now included factors such as client / customer pressure, ability to compete successfully with competitors, improve product / service quality, and obtain approved supplier status. The benefits of related marketing were realized by several organizations (Rayner and Porter, 1991; Street and Fernie, 1992). However, some organizations were also aware of internal benefits such as business process improvement and product quality, but this seemed to happen by chance (Boiral, 2003). Organizations registered in ISO 9000 had greater results than their business operations (Ebrahimpour et al., 1997; Terziovski et al., 2003). The comparison of the financial performance of registered organizations with unlisted organizations of ISO 9000 was that there was little difference between the two (Terziovski et al, 1997; Five et al., 2000; Rahman, 2001).

Interpretation of ISO 9000:2000:

- Quality System Clauses Management Responsibility (Pramudya Sunu, 1999: 75);

- Quality System (Rudi Suardi, 2001: 82);

- Review of Contract (Sr. Nugroho, 1997: 157); 
- Design Control (Pramudya Sunu, 1999: 40);

- Control of Documents and Data (Bambang and Sulistijarningsih, 2000: 67);

- Purchase (Zulian Yamit, 2001: 159);

- Product Customer Supply Control;

- Identification and Ability to Search Products (Gilang P, 1996: 100);

- Process Control (Bambang and Sulistijarningsih, 2000: 73);

- Inspection and Testing (Zulian Yamit, 2001: 162);

- Control of Inspection, Measuring and Testing Tools;

- Status of Inspection and Testing (Zulian Yamit, 2001: 164);

- Unsuitable Product Control (Rudi Suardi, 2001: 119);

- Correction and Prevention (Pramudya Sunu, 1999: 97);

- Handling, Storage, Packaging, and Submission (S. Nugroho, 1997: 123);

- Quality Record Control (Zulian Yamit, 2001: 167);

- Internal Quality Audit (Zulian Yamit, 2001: 168);

- Training (Bambang and Sulistijarningsih, 2000: 47);

- Service (Zulian Yamit, 2001: 169);

- Statistical Techniques (Bambang and Sulistijarningsih, 2000: 67).

The four roles that arose from this quadrant and the four ways human resource professionals may contribute, based on two fixed axes, were shown in Figure 1.

\section{Future / Strategic Focus}

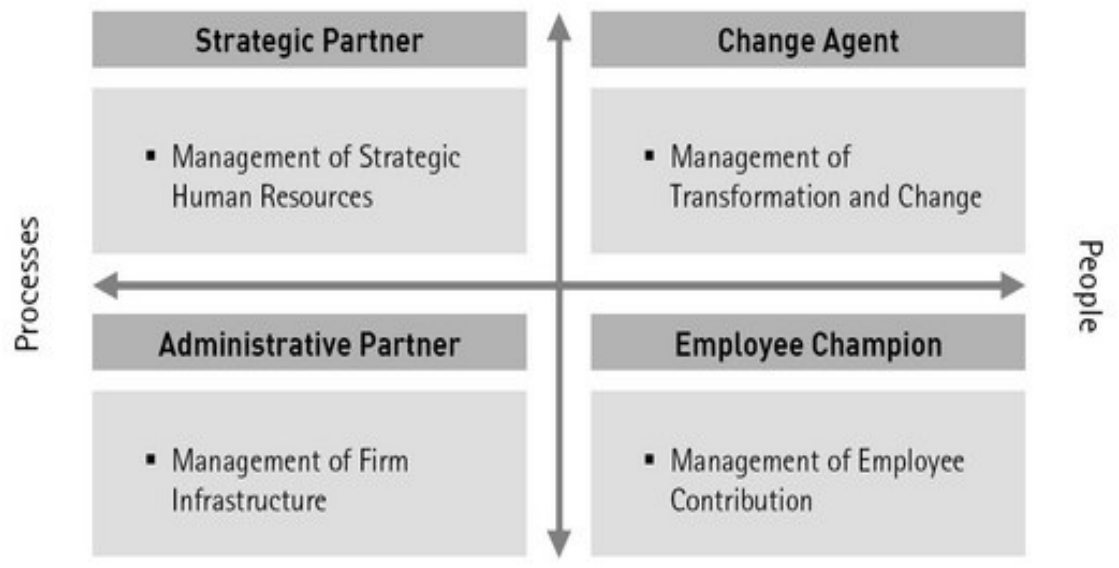

\section{Day-to-Day / Operational Focus}

Figure 1 - The Ulrich Model

Source: Ulrich, D. (1997). "Human Resource Champions: The Next Agenda for Adding Value and Delivery Results". Harvard Business School Press

The Role of Strategic Partners. According to Ulrich (1997), the key to enable human resource to play role as a strategic partner is to participate in the process of defining business strategy, instead of just responding to the strategy presented by "senior management". Eisenstat (1996) pointed out the paradox of pressure in roles such as discussing the executive's desire for professional human resources to serve as a strategic partner, while also expecting them to perform traditional administrative and control functions downgraded to human resources. The role of an inherently strategic partner implies that human resources work together with the organization's managers in developing, improving and implementing strategies. In today's organizations, to ensure the viability and ability to contribute to them, human rsource managers must consider themselves as strategic partners. The role of human resource professionals analyzes and evaluates the organization's financial position (Mathis, \& Jackson, 2007). 
The Role of Change Agent. This role makes it easier to introduce and adapt from faster changes. This can be achieved through training of new technology operations staff (Lawler \& Boudreau, 2009). If the organization needs more staff i.e expert staff, human resources should be able to recruit the staff. It also handles what customers expect from the organization. It is used to evaluate business satisfaction for customers (Holbeche, 2008). Kesler (2000) writes that the role of human resource in change varies between organizations, but if society cannot define the processes and priorities of change efforts, it is not an effective player in the organization. Defined more closely, the role of change agents helps to refer to organizations building capacity for change (Conner \& Ulrich, 1996). Csoka (1995) further demonstrates that human resource professionals can add significant value through managing organizational change processes. Ehrlich (1997) adds that the human resources department should anticipate change and have knowledge in its implementation. Baird and Meshoulam (1998) state that the effectiveness of human resource management depends on the stage of organizational development.

The Role of Employee Champion. The role of superior workers has not been significant in human resource management (Pride \& Hughes, 2009). Organizations in the past used to have a good strategy for employees. It provides security for them and hopes for promotion in the workplace. But this is no longer an effective way to communicate between staff and management (Daft, 2008). Human resources ensure that employees have skills that enable them to meet organizational goals. It is also responsible for motivating employees so as to provide a good working environment. This ensures they get a better salary. Good service depends on the ability of human resources to coordinate employees in an orderly manner.

The Role of Administrative Expert. Another role is the role of administration. A professional human resource is an expert in executive roles. They ensure that the operation runs as it is set. They must work to reduce costs and improve benefits and ensure the achievement of organizational efficiency and effectiveness. This executive should always analyze how the workflow takes place within an organization. They are responsible for rethinking the mode of operation in business (Dubrin, 2008). Allowing part of a company to share the services of human resource professional executives should try to get the job done faster and cheaper.

The four roles identified above are responsible for organizational well-being (Bohlander \& Snell, 2009). They work together and without any of them it is difficult to achieve success. But this model faces several challenges. Technological improvements are a major challenge. Businesses or organizations try to catch up with technological change. Globalization is another factor. Organizations must improve their products to handle global settlements.

Performance Concepts. Performance terminology is quite popular among the public and is generally understood and clearly defined. Performance means something that has been done (done thing) and is a work that can be achieved by a person or group of people in the organization in accordance with the authority and responsibility of each in order to achieve organizational goals (Suyadi, 1999). Another opinion about the performance proposed by Osborne (1990), performance is defined as the level of achievement of an organizational mission. According to this understanding, performance is defined as the extent to which the organization is able to achieve its mission.

Inadequate performance of performance of organization is only done by using the indicators attached to the organization such as efficiency, effectiveness, but must also be seen from the indicators inherent in service users such as satisfaction, accountability and responsiveness. For that purpose, the authors use performance appraisal by referring opinion Dwiyanto (2008) that is:

- Productivity;

- Quality of service;

- Responsiveness;

- Responsibility;

- Accountability.

Based on review of the literatures and the findings of other previous studies, the research hypotheses are 1). The implementation of ISO 9000 has an effect towards the 
performance of the ISO standardized public health centers in Central Sulawesi; and 2). the strategic role of MSDM influences the performance of the ISO-standardized public health centers in Central Sulawesi.

\section{METHODS OF RESEARCH}

The study was descriptive-causality research. This type of research will test the hypothesis in empirical research model. The data were cross sectional data. The setting was four regencies/ cities in Central SulawesiPalu, Donggala, Banggai, and Poso. Since the number of target population is relatively small then this research would use census method. The total respondents were 183 respondents. The data analysis method was path analysis (The Structural Path Analysis) from the AMOS 22 statistical software package.

\section{RESULTS OF STUDY}

Figure 2 described the result of the data analysis.

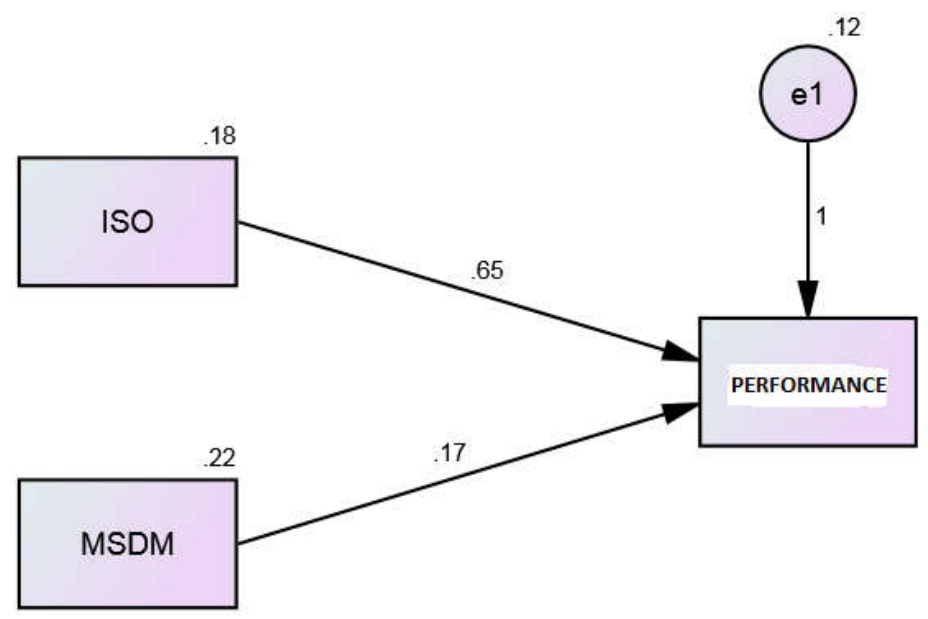

Figure 2 - Path Analysis Results

Table 1 described Figure 2 in a more elaborated manner.

Table 1 - Contribution of X1 = ISO 9000, X2 = MSDM Strategic Role towards $Y=$ Performance of ISO standardized public health centers in Central Sulawesi and $\mathrm{P}=$ Probability of the Significance

\begin{tabular}{|c|c|c|c|c|c|c|}
\hline \multicolumn{2}{|c|}{-} & Estimation & S.E. & C.R. & P \\
\hline $\mathrm{Y}$ & $<---$ & $\mathrm{X} 1$ & .655 & .059 & 11.026 & ${ }^{\star \star *}$ \\
\hline $\mathrm{Y}$ & $<---$ & $\mathrm{X} 2$ & .168 & .055 & 3.072 & .002 \\
\hline
\end{tabular}

Based on Table 1, ISO 9000 had 0.65 or $65 \%$ influence towards the performance of the public health centers with probability of 0.000 at level of significance $\alpha=5 \%$. The strategic role of human resource management had 0.17 or $17 \%$ influence towards the performance of the public health centers with the probability of 0.002 and the level of significance $\alpha=5 \%$. The ISO 9000 and the strategic role of human resource management simultaneously had 0.419 or $41.9 \%$ influence towards the performance of the ISO standardized public health centers in Central Sulawesi. The rest was influenced by other factors not examined in this study.

\section{DISCUSSION OF RESULTS}

ISO 9000 has a significant effect on the performance of the ISO standardized public health centers in Central Sulawesi with $\alpha=5 \%$. It is proven by probability value or P-Value 
$0.000<\alpha(0,05)$. It can be interpreted that the ISO 9000 consisting of; management responsibilities, quality system, contract review, design control, document and data control, purchasing, product supply control, product identification and traceability, process control, inspection and testing, inspection control, measuring and testing, inspection and testing , Inappropriate product control, corrective and preventive measures, handling, storage, packaging and delivery, quality recording control, internal quality audit, training, and service contributes $65 \%$ towards the performance of the ISO standardized public health centers in Central Sulawesi.

The strategic role of human resource management has a significant effect on the performance of the ISO standardized public health centers in Central Sulawesi with $\alpha=5 \%$. The evidence was, probability value or P-Value $0.002<\alpha(0.05)$. Thusm it can be interpreted that the strategic role of human resource management consisting of; The role of strategic partners, the role of change agents, the role of superior workers, and the role of administrative experts contributed $17 \%$ towards the performance of the ISO standardized public health centers in Central Sulawesi.

The ISO 9000 and the strategic role of human resource management simultaneously had 41.9 contributions towards the performance of the ISO standardized public health centers in Central Sulawesi. This provides an understanding that the $41.9 \%$ of the performance of the public health centers in Central Sulawesi is affected by both variables.

\section{CONCLUSION}

The ISO 9000 and the strategic role of human resource management have simultaneous and partial contribution towards the performance of the ISO standardized public health centers in Central Sulawesi.

Moreover, it can be suggested that the ISO certification that has been obtained should to be maintained in order to gain trust of stakeholders who may sometimes grant aid to institution. As an addition, the four strategic roles of human resource management should complement and support each other in achieving excellent performance.

\section{REFERENCES}

1. Baird, L \& Meshoulam, I. 1998. Managing Two Fits of Strategic Human Resource Management. The Academy of Management Review. Mississippi State. 13 (1), 116-129.

2. Beattie, K.R. And Sohal, A. 1999. "Implementing ISO 9000: a study of the benefits among Australian organizations", Total Quality Management, Vol. 10 No. 1, pp. 95-106.

3. Becker, B.E. \& Huselid, M.A. 1998. High performance work systems and firm performance: a synthesis of research and managerial implications. Research in Personnel and Human Resources Management, 16, 53-101.

4. Berwick, D.M. 1989. "Continuous improvement as an ideal in health care", New England Journal of Medicine, Vol. 320, pp. 53-6.

5. Bohlander, G. \& Snell, S., 2009. Managing Human Resources. 15th ed. New York: Cengage Learning.

6. Boiral, O. 2003. "ISO 9000: outside the iron cage", Organization Science, Vol. 14 No. 6, pp.72-137.

7. Carlsson, M. and Carlsson, D. 1996. "Experiences of implementing ISO 9000 in Swedish industry", International Journal of Quality and Reliability Management, Vol. 13 No. 7, pp. 36-47.

8. Carr, S., Mak, Y.T. And Needham, J.E. 1997. "Differences in strategy, quality management practices and performance reporting systems between ISO accredited and non-ISO accredited companies", Management Accounting Research, Vol. 8 No. 4, pp. 383-403.

9. Carson, B.E. 2004. ISO 9001: 2000: A New Paradigm for Health Care, ASQ Quality Press, Milwaukee, WI. 
10. Cho, S., \& Mayer, K.J. 2003. Measuring the Impact of HRM Practices on Performance of organization. Proceedings of ICHRIE, Palm Springs, CA.

11. Cho, Y. Seonghee. 2004. Examining the Impact of Human Resources Management: A Performance-Based Analytical Model, Unpublished Dissertation, Graduate College, University of Nevada, FL.

12. Conner, J \& Ulrich, D. 1996. Human Resource Roles: Creating Value, Not Rhetoric. HR. Human Resource Planning: Tempe. 19 (3), pg 38.

13. Csoka, Louis S. 1995. Rethinking Human Resources: A Research Report.New York. The Conference Board.

14. Daft, L., 2008. New era of management. 2nd ed. New York: Cengage Learning EMEA.

15. Dicket, G., Gallimore, K. and Brown, J. 2002). Does ISO 9000 accreditation make a profound difference to the service quality is perceived and measured? ", Managing Service Quality, Vol. 12 No. 1, pp. 30-42.

16. Dubrin, J., 2008. Essentials of Management. 8th ed. New York: Cengage Learning.

17. Dwiyanto, A. 2008, Public Organization Performance Assessment: State Administration Science Department, Yogyakarta. Fisipol UGM.

18. Ebrahimpour, M., Withers, B. and Hikmet, N. 1997. "Experiences of US- and foreignowed firms: a perspective on ISO 9000 implementation", International Journal of Production Research, Vol. 35 No. 2, pp. 569-76.

19. Ehrlich, C. J. 1997. Human resource management: a changing script for a changing world. (Special Issue on the Future of Human Resource Management) Human Resource Management.36 (1), 85-90.

20. Eisenstat, Russell A. 1996. Four models for functional management. Organizational Dynamics.25 (2), 6-14.

21. Gilang Priyadi S, 1996. Implement SNI Series 9000 ISO 9000 (Series) Product Manufacturing, Earth Script, Jakarta.

22. Holbeche, L. 2008. Aligning Human Resources and Business Strategy. 2nd ed. New Jersey: Butterworth-Heinemann.

23. Hughes, T., Williams, T. and Ryall, P. 2000. "It is not what you achieve it is the way you achieve", Total Quality Management, Vol. 11 No. 3, pp. 329-40.

24. Huselid, M.A., 1995. The Impact of Human Resource Management Practices on Turnover, Productivity and Corporate Financial Performance, Academy of Management Journal, 38 (3), 635-672.

25. Institute of Medicine. 2001. Crossing the Quality Chasm: A New Health System for the 21st Century, National Academy Press, Washington DC.

26. Ismail R, and Syamsuddin, 2007. Impact of ISO 9000 Quality System Implementation on Processed Wood Industry Performance in Donggala Regency Central Sulawesi (Study on Exported Wood Processing Industry in Donggala Regency, Central Sulawesi), Fundamental Research of DP2M Dikti, Tadulako University, Palu.

27. Jones, R., Arndt, G. and Kustin, R. 1997. "ISO 9000 among Australian companies: the International Journal of Quality and Reliability Management, Vol. 14 No. 6/7, pp. 650-60.

28. Katerina D. Gotzamani and George D. Tsiotras, 2001. An empirical study of the ISO 9000 standards' contribution towards total quality management. International Journal of Operations \& Production Management, Vol. 21 No. 10, 2001, pp. 1326-1342. MCB University Press.

29. Kesler, Gregory. 2000. Four steps to building an HR agenda for growth: HR strategy revisited. HR. Human Resource Planning. Tempe 2000. 23 (3), 24-37.

30. Lawler, E., Boudreau, A., 2009. Achieving Excellence in Human Resource Management. London: Stanford University Press.

31. Lee, K.S. And Palmer, E. 1999. "An empirical examination of ISO 9000-listed companies in New Zealand", Total Quality Management, Vol. 10 No. 6, pp. 887-99.

32. Lima, M.A.M., Resende, M. and Hasenclever, L. 2000. "Quality certification and performance of Brazilian firms: an empirical study", International Journal of Production Economics, Vol. 66 No. 2, pp. 143-7. ISO 9000 series of standards 141 
33. Maruf Hasan, Ali, Lam. 2007. ISO 9000 and TQM for Business Excellence. The University of New South Wales, Sydney 2052, Australia

34. Mathis, R.L., \& Jackson, R.H., 2007. Strategies of human resources management. 6th ed. New York: Cengage Learning.

35. Mattulada A, and Syamsuddin, 2008. Impact of Public health center Service Quality on Satisfaction of Poor Family and Non Poor Family Service Users in Central Sulawesi (Studies at TQM and Non TQM Community Health Centers in Central Sulawesi), Fundamental Research of DP2M Dikti, Tadulako University, Palu.

36. McAdam, R. and Canning, N. 2001. "ISO in the service sector: perceptions of small professional firms", Managing Service Quality, Vol. 11 No. 2, pp. 80-92.

37. McAdam, R. and Fulton, F. 2002. "The impact of the ISO 9000: 2000 quality standards in small software firms", Managing Service Quality, Vol. 12 No. 5, pp. 336-45.

38. Osborne, David. 1990. Organizational Theory an Intergrated Approach. United States: Perseus Book Publisshing.

39. Pramudya Sunu, 1999. Role of HR in Implementing ISO 9000 Human Resource Role with TQM Approach, Gramedia Widiasarana Indonesia, Jakarta.

40. Pride, W., Hughes, R, 2009. Business. 10th ed. New York: Cengage Learning.

41. Rahman, S. 2001. "A comparative study of TQM practice and performance of organization with and without ISO 9000 certification", International Journal of Quality \& Reliability Management, Vol. 18 No. 1, pp. 35-49.

42. Rayner, P. and Porter, L. 1991. "BS5750 / ISO9000 - the experience of small and medium-sized firms", International Journal of Quality \& Reliability Management, Vol. 8 No. 6, pp. 16-28.

43. Rudi Suardi, 2001. Quality Management System ISO 9000: 2000 Its Implementation To Achieve TQM, PPM Management Institute, Jakarta.

44. S. Nugroho, 1997. ISO 9000 Series and SNI Series 19-9000-1992 Version 1987 and 1994, Abdi Tandur, Jakarta.

45. Singles, J., Ruel, G. and Water, H. 2001. "ISO 9000 series: certification and performance", International Journal of Quality and Reliability Management, Vol. 18, No. 1. Pp. 62-75.

46. Sluijs, E.M. And Wagner, C. 2000.Quality Systems in Health-Care Organizations. Present Situation in 2000, Nivel, Utrecht.

47. Stelzer, D., Mellis, W. and Herwurm, G. 1997. "A critical look at ISO 9000 for software quality management", Software Quality Journal, Vol. 6 No. 2, pp. 65-79.

48. Street, P. and Fernie, J. 1992. "BS 5750: the industry view", International Journal of Quality \& Reliability Management, Vol. 9 No. 7, pp. 37-41.

49. Sulaeman M and Mukhtar T, 2009. Implementation of ISO 9000 Quality System to Public health center Performance in Palu City (Survey at Public health center TQM in Palu City), Fundamental Research of DP2M Dikti, Tadulako University, Palu.

50. Sulaeman M and Syamsuddin, 2008. Impact of ISO-9000 Quality System Implementation on Public Hospital Performance in Palu Central Sulawesi (Survey on Public and Private Public Hospital in Palu City), Fundamental Research of DP2M Dikti, Tadulako University, Palu.

51. Suyadi Prawirosentono, 1999, Employee Performance Policy; Tips for Building a Competitive Organization Toward World Free Trade, BPFE Yogyakarta.

52. Syamsuddin, 2006. Effect Analysis of Quality System Implementation of ISO 9000 on Operational Performance of Large-scale Wood Industry in Palu City, Research of Young Lecturer of DP2M Dikti, Tadulako University, Palu.

53. Syamsul Bahri DP and Syamsuddin, 2009. Human resource development system in increasing intellectual capital and its effect on employee performance and performance of health center in Palu city, Fundamental Research of DP2M Dikti, Tadulako University, Palu.

54. Taylor, W. 1995a.Senior executive and ISO 9000: Attitudes, Behavior and Commitment", International Journal of Quality \& Reliability Management, Vol. 12 No. 4, pp. 40-57. 
55. Taylor, W. 1995b "Organizational differences in ISO 9000 implementation practices", International Journal of Quality \& Reliability Management, Vol. 12 No. 5, pp. 10-27.

56. Terpstra, D.E. \& Rozzell, E.J. 1993. The relationship of staffing practices to organizational level measures of performance. Personnel Psychology, 46: 27-48.

57. Terziovski, M., Power, D. and Sohal, A. 2003. "The Longitudinal Effects of the ISO 9000 certification process on business performance", European Journal of Operations Research, Vol. No. 146 3, pp. 580-595.

58. Terziovski, M., Samson, D. and Dow, D. 1997. "The Business Value of Quality Management Systems Certification: Evidence from Australia and New Zealand", Journal of Operations Management, Vol. 15 No. 1, pp. 1-18.

59. Ulrich, D. 1997. Measuring Human Resource: An Overview of Practice and a Prescription for Results. HRM, 36 (3), 303-320.

60. Van den Heuvel, J., Hendriks, M.J. And van Waes, P.F.G.M. 1998. "An ISO-quality system in the radiology department: a benefit analysis", Academic Radiology, Vol. 5, suppl. 2, pp. S441-5.

61. Yeung, A. C. L., Lee, T. S. and L. Y. Chan. 2003. Senior management perspectives and ISO 9000 effectiveness: an empirical research. International Journal of Production Research. 41: 545-569.

62. Zulian Yamit, 2001. Quality Management of Products and Services, First Edition, Econisia, Yogyakarta. 